\title{
Self-Efficacy and Self-Care of a Working Mother-Student during COVID-19 Pandemic
}

\section{Choe Chai Tan and Noor Syamilah Zakaria}

To Link this Article: http://dx.doi.org/10.6007/IJARBSS/v11-i12/11784

DOI:10.6007/IJARBSS/v11-i12/11784

Received: 15 October 2021, Revised: 20 November 2021, Accepted: 30 November 2021

Published Online: 23 December 2021

In-Text Citation: (Tan \& Zakaria, 2021)

To Cite this Article: Tan, C. C., \& Zakaria, N. S. (2021). Self-Efficacy and Self-Care of a Working Mother-Student during COVID-19 Pandemic. International Journal of Academic Research in Business and Social Sciences, 11(12), 2437-2451.

\section{Copyright: (c) 2021 The Author(s)}

Published by Human Resource Management Academic Research Society (www.hrmars.com)

This article is published under the Creative Commons Attribution (CC BY 4.0) license. Anyone may reproduce, distribute, translate and create derivative works of this article (for both commercial and non0-commercial purposes), subject to full attribution to the original publication and authors. The full terms of this license may be seen at: http://creativecommons.org/licences/by/4.0/legalcode

\section{Vol. 11, No. 12, 2021, Pg. 2437- 2451}

Full Terms \& Conditions of access and use can be found at http://hrmars.com/index.php/pages/detail/publication-ethics 


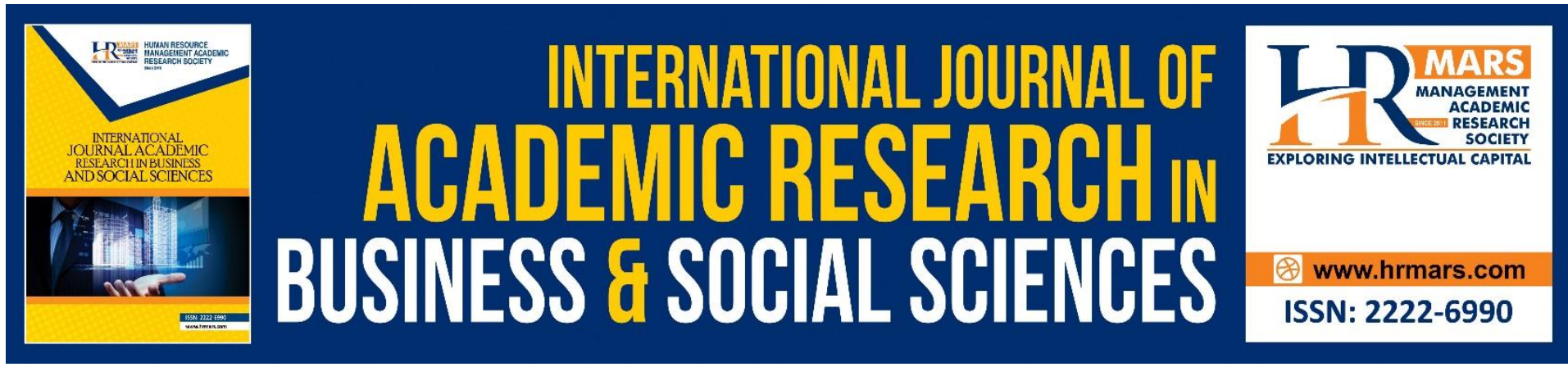

\title{
Self-Efficacy and Self-Care of a Working Mother- Student during COVID-19 Pandemic
}

\author{
Choe Chai $\operatorname{Tan}^{1,2}$ and Noor Syamilah Zakaria ${ }^{1}$ \\ ${ }^{1}$ Faculty of Educational Studies, Universiti Putra Malaysia, Malaysia, ${ }^{2}$ General Studies \\ Department, Sunway College, Malaysia \\ Email: celinet@sunway.edu.my, syamilah@upm.edu.my
}

\begin{abstract}
Nobody expected the COVID-19 pandemic which has affected every facet of our lives. The focus of this paper is to explore the impact of the COVID-19 pandemic on the mental health of the working mother-student. Hence, the need to evaluate and understand how the selfefficacy practices of working mother- student has changed during the pandemic. The methodology used is the narration of personal reflection of a mother's experience in taking care of her husband, a COVID-19 patient, while pursuing her PhD during the peak of the pandemic in Malaysia. The findings of the study are elaborated in this paper. The study focuses on the details and challenges of the quarantine period and the techniques to overcome these challenges, such as mastery experiences, social persuasion, physiological and emotional states. Through personal narratives, common adverse psychological consequences of quarantine were identified. Self-acceptance, self-compassion, and self-care were elaborated to enhance self-efficacy during and beyond the pandemic.
\end{abstract}

Keywords: COVID-19, Self-Efficacy, Self-Care, Self-Compassion, Self-Acceptance

\section{Study Objectives}

- To explore the self-efficacy of a working mother-student during COVID-19 pandemic

- To understand the self-care of a working mother-student during challenging times

- To study the personal reflections of a working mother-student from the perspective of self-efficacy, mastery experiences, social persuasion, physiological and emotional states.

- To investigate how self-efficacy, self-acceptance, self-compassion, and self-care are necessary protocols to reduce the negative effects on the psychology of patients and caregivers during challenging times.

\section{Introduction}

Since the World Health Organization (WHO) pronounced COVID-19 as a pandemic on 18 March 2020, most countries are still battling with the devastating effects of the novel virus. The capacity to control the spread of the virus differed between countries. According to Bloomberg's COVID-19 Resilience Ranking, New Zealand, Singapore and Australia are the top three countries that had effectively controlled the pandemic (Hong et al., 2021). The majority of high and upper-middle-income countries have vaccinated a high proportion of their 
population; however, the opposite scenario plays out in low-income countries (Holder, 2021). Likewise, the standard operating protocols (SOP) in curbing the pandemic are dynamic in several countries worldwide. While some countries are more likely to relax and loosen the SOPs, others are experiencing an upward swing of cases.

Initially, Malaysia was among the top countries in managing the first wave of COVID-19 earlier in 2020. Unfortunately, the number of daily cases began to show an increasing trend in September 2020 immediately after the election held in Sabah. As of 2021, the cases escalated following the Raya celebration. According to the Health Director-General, activities preceding the Hari Raya period contributed significantly to the spread of COVID-19 in Malaysia (Povera \& Arumugam, 2021). Malaysia's Ministry of Health reported that a total of 565,533 confirmed cases of COVID-19 had been detected as of 30 May 2021. This led to the implementation of a total lockdown, Movement Control Order 3.0 (MCO 3.0) from 1 June 2021 to 16 June 2021 to flatten the spread. The state of Selangor, which is where I presently reside, experienced the worst outbreak of the pandemic in Malaysia (Hirschmann, 2021).

I am inspired by the interest of Feminist Frontiers to assess reflections and experiences faced by women during COVID-19. This has motivated me to share exclusive insights and experience as a working mother and part-time doctoral student in coping with the pandemic. This personal reflection is based on Bandura's self-efficacy concept (1997). As a working mother and a student, I believe in my ability to take care of my well-being, including that of my family, my career, and my studies. In the middle of this unexpected event, someone dear to me was confirmed to have COVID-19. Motlagh et al (2019) revealed that people with a high level of self-efficacy are keener to practice self-care in difficult times. Mastery experiences, social persuasion, physiological and emotional states in Bandura's self-efficacy concept (1997) will be used as references to my lived self-care experiences during this pandemic.

This personal reflection is based on the self-efficacy of my lived experiences of taking care of my husband (L) who was a confirmed COVID-19 patient. Using the aforementioned theory as a guide, I elaborate my emotional experiences as a caregiver of close contact, while observing and practicing self-care concurrently.

\section{The Third Wave of Covid-19 in Malaysia}

Before $L$ was detected to have COVID-19, he was operating his workshop as usual because it was considered an essential service. He was extremely cautious in his contact with others, wears a mask, sanitizes his hands frequently, and was consistent with the SOPs. For instance, in his workplace, if he sees any of his business partners or staff not wearing masks properly, he will correct them immediately. In fact, his strictness on mask issues affected the atmosphere at the workshop. He also exemplified a similar strict requirement at home.

To avoid any chances of contracting COVID-19, he was observing the SOPs more strictly than the authority's requirement. He practiced takeaway lunch while working but he was once invited by his business acquaintance for lunch near his workshop. A few days later, he experienced a mild scratchy throat, with no other symptoms. He went to the clinic and was examined by a doctor. As the number of confirmed cases was high (few thousand each day), the doctor jokingly suggested to him to do a COVID-19 test. As a cautious person, he agreed and did the RTK-Ag (Antigen Rapid Test Kit) test. To his surprise, he was tested positive. He informed me about the result while still in a state of unbelief. I was in the office and quickly informed my colleagues on WhatsApp and packed my stuff in a few seconds and left office immediately. 
On getting home, my two children and I went to conduct a Antigen Rapid Test Kits (RTK$\mathrm{Ag}$ ) test to know our status. All of us tested negative but afraid of what it could be, we decided to self-quarantine for 10 days. $L$ was worried that his self-quarantine at home might be risky for family members, so he called up the quarantine center. However, the officer advised him to quarantine at home as the center was already full. Also, he was advised to call if he develops symptoms such as fever, breathing difficulty, or other serious conditions. Given his worried state, he called a nearby private hospital only to be informed again that beds for COVID-19 patients were full.

L continued searching and contacted another private hospital. The officer invited him for the Reverse Transcription Polymerase Chain Reaction (RT-PCR) test and to see a doctor. Without wasting time, he secured an appointment with them and did the RT-PCR test. Upon assessing his condition, the doctor reaffirmed that his lung capacity and other aspects were good. Also, the doctor advised him to self-quarantine, and no medication was given since he had no symptoms. $L$ knows that he needs to quarantine himself as soon as possible to avoid spreading the virus. He started his home self-quarantine on the day he tested positive following the RTK-Ag test. Finally, his positive status was reconfirmed by the RT-PCR test and he received his result on the second day of quarantine.

Aside from controlling the spread of the virus, the full movement control order (FMCO) from June 1 to June 14, 2021 was implemented by Malaysia government to reduce the pressure on hospitals and front liners (Povera et al., 2021). At that moment, we were concerned about the news of emerging new variants of the virus and the potential impact. This is complicated by the fact that infected persons may not show symptoms and they can easily spread the virus, thus, resulting in high fatality rates (Bernama, 2021). The uncertainty of what will happen to our lives, livelihood, and future dragged us to the stage of shock and disbelief on the day my husband was diagnosed with COVID-19.

\section{Mastery Experiences}

I am a teacher at a private college, holder of a master's degree in guidance and counseling, and currently pursuing my doctorate. I am always mindful of my emotional needs and stressors due to my hectic lifestyle. I admit that when I received the news that $L$ was positive for COVID-19, my mind was blank and I could not believe the result. However, following the confirmation based on his RT-PCR test result on the second day, we had to accept the fact that he had contracted the virus.

During the 10 days quarantine, aside from my usual role as a mother, a worker, and a student, I had to be a nurse, a cook, and the only caregiver of my husband. He was quarantined in the master bedroom upstairs, while I stayed downstairs. Our two children were also quarantined separately in different rooms. I wore a mask at home and surgical gloves to handle his clothes and to deliver meals to the door of his room. In addition, his temperature and symptoms were monitored daily from the day he was diagnosed till the quarantine was over. I undertook all the monitoring and care.

In the middle of the traumatic experience, I started writing my daily feelings in a diary to keep track of my emotion. Expressing my feeling in writing was really a peaceful experience and I practiced it every morning, after meditating for 15 minutes. Sometimes, the meditation may be insufficient to calm me down but I felt relieved emotionally upon expressing my anxiety by writing on the dairy. 


\section{Social Persuasion}

In social media, the slogan, "keep social distancing" to break the coronavirus chain is common but it may mislead to the viewpoint of isolating oneself socially. In the words of Saltzman et al (2020), the more proper term should be "physical distancing". As interdependent creatures, human beings are generally active socially throughout their lives. Moreover, social support is more needed than usual, especially during difficult times such as the current pandemic. Hence, "keep physical distancing" is a must during the pandemic but not "social distancing".

During our 10 days quarantine, we received a lot of social support but we maintained physical distancing throughout the period. On the second day after my husband was diagnosed, my close family members and friends sent numerous materials to us such as traditional Chinese medicines (TCM), fruits, vegetables, fresh fish, eggs, and food supplements. While some of my family relatives and friends called us directly, others sent messages to enquire about the things we needed during the quarantine period. Thereafter, they helped us to purchase the things we requested and delivered them to our doorstep. In fact, some of them went beyond our request by providing what they felt will be useful under such a condition. They left the materials outside the gate and called to inform me to collect them after they left. I was overwhelmed with their assistance, care, and support.

Nonetheless, during the home self-quarantine, the physical distancing affected our psychological health despite the immense social supports. The feeling of isolation might pop out from nowhere. Although my two sons and husband stayed under the same roof, we had to keep physical distance all the time. This made me felt restless, uneasy, and weird. Though I knew it was necessary and compulsory to self-quarantine, it affected us emotionally.

On top of the restlessness, the worry of the spread of the virus can also be overwhelming, especially when we receive news from social media as the number of COVID19 cases kept on increasing during the duration in Malaysia. There were several worrisome information that affected me emotionally. For instance, there were reports of asymptomatic patients developing to the end stage and death (Del Nonno et al., 2021), and some patients died before they were admitted to the hospital or brought in dead (BID) (Salim, 2020). More importantly, mortalities due to 'silent hypoxemia' or 'happy hypoxia' may occur in asymptomatic patients.

Caregivers need to be observant by not only relying on the apparent health of the patient but frequently check their breathing rate, hyperventilation signs, and oxygen level (Dhont et al., 2020). The news of the emergence and spread of new variants (the United Kingdom [UK] variant, Indian variant, Brazil variant, and South African variant) in Malaysia (Povera et al., 2021) remains a big concern. Furthermore, the new variants spread easily and cause significantly higher mortality rates (Kelland, 2021; Le Page et al., 2021). Back to my experience, all these facts and information added to my stress of taking care of a COVID-19 patient. As I do not have the medical knowledge to handle a COVID-19 patient, I updated myself with the correct information from trustable sources and screening through reliable sources and practical methods to assist L. As suggested by Banerjee (2020), the families of the patients should be updated with relevant facts and be adequately informed to reduce uncertainty. Supportive interventions and social connection arrangements need to be promptly provided to assist them in minimizing loneliness. It is important to ensure patients in isolation have sufficient supplies with dignity. 


\section{Physiological and Emotional State}

I had to remind myself that I could handle the challenging situation despite being an unexpected event. My goal for the 10 days quarantine was that $L$ will recover fully and all our family members will not be infected with COVID-19. I believed that with proper care, it was achievable since self-efficacy is a vital factor that supports the achievement of a goal (Bandura, 1997). Nevertheless, I was aware of my worries and concerns during the quarantine. I allowed myself to be aware of such worries by re-affirming that it is normal. If the worries became too difficult to handle, I sought help from trusted friends who could assist. Below are the daily quarantine records. 
TABLE 1 Daily quarantine records

\begin{tabular}{|c|c|}
\hline Date & Emotional State \\
\hline $\begin{array}{l}6 / 5 / 2021 \\
\left(1^{\text {st }} \text { day) }\right.\end{array}$ & 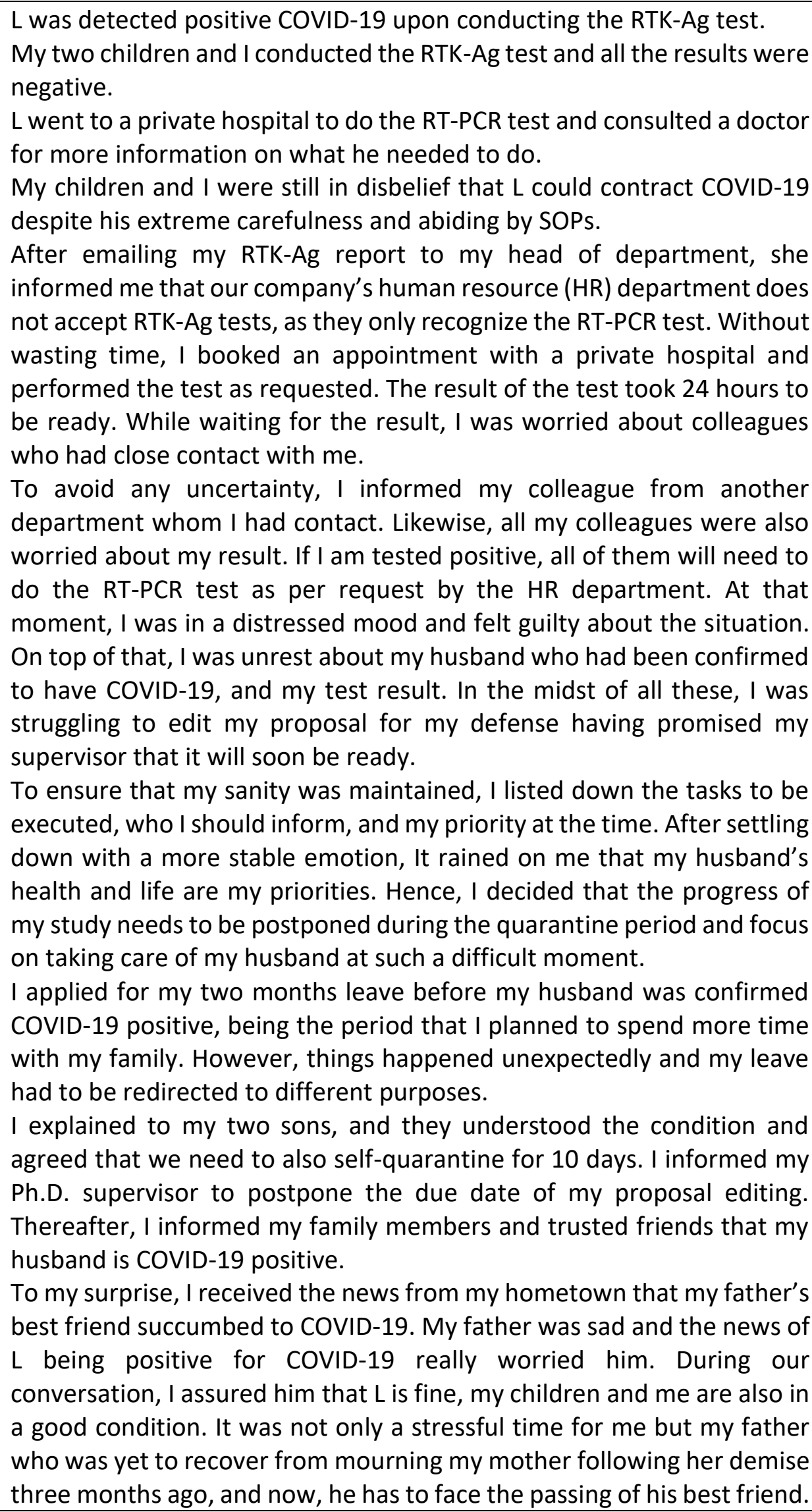 \\
\hline
\end{tabular}


I decided not to inform others about my husband's confirmed case due to several negative news in our society. Receiving the news of our beloved friends contracting COVID-19 can be depressing. So, we just informed whoever had physical close contact with us during the past week to prevent spreading the virus.

7/5/2021 I felt unsettled. L had received the RT-PCR test result and confirmed $\left(2^{\text {nd }}\right.$ day) positive. It was stressful. The stress was inevitable but we remained calm. Reminding myself, I could handle the situation, he will recover and all of us will be fine. In the afternoon, I received an email from the hospital that my RT-PCR test was negative. I was happy that my colleagues do not need to go through the RT-PCR test because of me. I quickly forwarded the result to my head of department and shared the news on the department's WhatsApp group.

Another good news was that all L's colleagues were confirmed negative for COVID-19.

L started taking the first dose of TCM since the doctor from the hospital did not prescribe any medication. Having conducted some online surveys, I found many testimonies that TCM is helpful for COVID-19 patients. The friend who gave us the TCM forwarded the contact of the TCM shop owner to me to double-check on the proper way to cook and prepare it.

L started to cough mildly with thick mucus secretion (i.e. phlegm).

I began to get used to the routine of a full-time caregiver. Early in the morning, I cook the TCM, prepare breakfast, and plan for lunch and dinner for the day.

8/5/2021 Since COVID-19 can be life-threatening, I was worried about the progress ( $3^{\text {rd }}$ day) of L's condition. There were cases of patients not showing symptoms in the first few days but deteriorated on either the $4^{\text {th }}$ or $5^{\text {th }}$ day, so I had to be very alert. However, he was quarantined in his room, I do not see him, so I was very conscious of his call through my handphone should there be any issue. I am thankful that I am living in the era of handphones. Without it, I have no idea how to communicate with him in this highly contagious condition.

The feeling of taking care of a COVID-19 patient was tense because you do not know what will happen next. The good news for today is his sore throat is better.

$L$ is taking his second dose of TCM. He had more phlegm and coughed out more than yesterday. He felt this is the effect of the TCM, and he was happy with the result.

9/5/2021 I was alert and reminded myself that his symptoms might show more in ( $4^{\text {th }}$ day) these two days.

At the end of the day, I felt relieved he did not have any of the symptoms of fever, shortness of breath, chest pain, loss of taste, joint pain, or any other symptoms related to COVID-19.

$L$ is taking his third dose of TCM. He stated having gastric issues. He complained of indigestion and felt bloated. 
Since I was still in quarantine and could not go out to get gastric medication for him. I was not sure of how to assist him.

My eldest sister from another state called and asked about L's condition. I told her what he was currently facing. She went to the TCM shop, bought a bottle of gastric powder, and sent it to us via courier. She got all the ingredients written by the seller and let us decide whether to take it or not. All the ingredients were common herbs. She was neither sure of the efficacy nor if it is helpful for his condition, but at least we had an option, whether to try it or bear with it. The medicine is scheduled to arrive in three days.

$10 / 5 / 2021 \quad$ I was glad that he did not show any new symptoms.

( $5^{\text {th }}$ day) Nevertheless, he was in a bad mood due to his gastric issue. I discussed with him the protocol of his treatment. Specifically, I advised him to listen to his body, since the side effects of the TCM were unbearable. Moreover, we react differently to medication.

After consideration, instead of completing six doses of TCM as prescribed, he stopped after the fourth dose.

L's elder sister called up and advised him to take six doses as prescribed by the TCM seller but he really felt to discontinue the medication. I encouraged him to make the decision. My advice was that nobody knows his body more than he does.

In this condition, some bereaved relatives might deem it necessary to advise on the issue. For them, that was the best solution but you know it is not. I think we need to gauge the pros and cons and make a decision. We appreciate their kindness but we need to decide on the protocol ourselves.

$11 / 5 / 2021 \quad$ In the morning, I felt relieved that $A^{\prime}$ 's condition was maintained. He is ( $6^{\text {th }}$ day) expected to recover accordingly based on his current condition. Unfortunately, I received bad news in the afternoon that his business partner, wife, his son, and fiancée were detected positive for COVID-19. It was shocking and I started to worry that the virus might have spread to our close contacts.

I tried to calm down and focus more on the positive things in life. I have to appreciate my present condition. At this moment, my children and I had no symptoms, therefore, I should be grateful that we are healthy and not infected. Moreover, our close family members and friends were very helpful and supportive and we have to appreciate their kind gestures.

$12 / 5 / 2021 \quad$ I received theTCM for gastric from my eldest sister but I was skeptical ( $7^{\text {th }}$ day) whether it will be effective for L. So, he just kept it in his room.

I still felt sorry for his business partner and family members who had contracted the virus. Due to their advanced age and pre-existing health conditions, his business partner and wife were admitted to the quarantine center under close observation. I was praying for their speedy recovery.

In such a hectic condition, I was in a dilemma. On one hand, I wanted the quarantine to be over soon, but on the other hand, I was worried 


\begin{tabular}{|c|c|}
\hline & $\begin{array}{l}\text { that time is against me to make any meaningful progress in my study. I } \\
\text { prayed that my children and I will not contact COVID-19 and I can } \\
\text { proceed with my research proposal editing. }\end{array}$ \\
\hline $\begin{array}{l}13 / 5 / 2021 \\
\text { (8 }{ }^{\text {th }} \text { day) }\end{array}$ & $\begin{array}{l}\text { L took the TCM and felt better with his gastric issue. } \\
\text { I was more relaxed compared to the first few days of quarantine and } \\
\text { already coping with the routine of cooking and preparing what he needs } \\
\text { systematically. } \\
\text { I started planning to pick up what I have left earlier in my studies. }\end{array}$ \\
\hline $\begin{array}{l}14 / 5 / 2021 \\
\text { (9 } 9^{\text {th }} \text { day) }\end{array}$ & $\begin{array}{l}\text { L continued with the medication and his gastric upset was subsiding. He } \\
\text { felt better, and was able to eat and sleep properly after suffering for } \\
\text { many days. } \\
\text { I started to edit my research proposal. I struggled at the beginning since } \\
\text { I had left it for quite some time. }\end{array}$ \\
\hline $\begin{array}{l}15 / 5 / 2021 \\
\left(10^{\text {th }} \text { day) }\right.\end{array}$ & $\begin{array}{l}\text { On the 10th day of the quarantine, I was thankful that } L \text { did not develop } \\
\text { other symptoms except for a mild scratchy throat. My children and I had } \\
\text { no symptoms. } \\
\text { The feeling was wonderful knowing that I will be free the next day to do } \\
\text { my grocery shopping. At that moment, I understood how a prisoner feels } \\
\text { when the day of freedom is fixed. }\end{array}$ \\
\hline $\begin{array}{l}16 / 5 / 2021 \\
\left(11^{\text {th }} \text { day) }\right.\end{array}$ & $\begin{array}{l}\text { It was a public holiday so } L \text { could not obtain a release letter from the } \\
\text { Department of Health. So, he decided to quarantine for one more day. } \\
\text { Immediately after the 10-day quarantine, I stepped out of my house for } \\
\text { the first time. At that moment, even driving a car was new to me. I Just } \\
\text { went out to do some grocery shopping and quickly came back home. I } \\
\text { felt insecure because my state was still recording the highest number of } \\
\text { daily confirmed cases in Malaysia. On top of that, asymptomatic patients } \\
\text { could be anywhere, so the best was to stay home. }\end{array}$ \\
\hline $\begin{array}{l}17 / 5 / 2021 \\
\left(12^{\text {th }} \text { day) }\right.\end{array}$ & $\begin{array}{l}\text { L went to the Department of Health in our district. He was there half an } \\
\text { hour before they started operating, however, the queue was already } \\
\text { long. After queuing for more than one hour, he was informed that only } \\
\text { workers needed to obtain a release letter to work. As an employer, he } \\
\text { does not need the letter. He was not satisfied with the wrong } \\
\text { information he got. } \\
\text { He came back home, called the staff at the health center who gave him } \\
\text { the information, and found out that the part-time staff was also wrongly } \\
\text { informed. The doctor in the Department of Health told him that he was } \\
\text { safe after completing the 10-day quarantine. } \\
\text { He was not sure of the validity of the information from the doctor } \\
\text { because he was not personally attended to. To double confirm that he } \\
\text { was safe and will not spread the virus, he went to see a doctor for clarity. } \\
\text { The doctor checked his throat, lung, blood pressure, and related } \\
\text { parameters that might be affected by CovID-19, and reaffirmed that he } \\
\text { was healthy. } \\
\text { A lot of misinformation might emanate because the Department of } \\
\text { Health is understaffed. Although it caused unnecessary time wastage, } \\
\text { we tried to understand that it is indeed a difficult time for everyone, } \\
\text { especially the front liners. In fact, this is a small issue compared to the }\end{array}$ \\
\hline
\end{tabular}




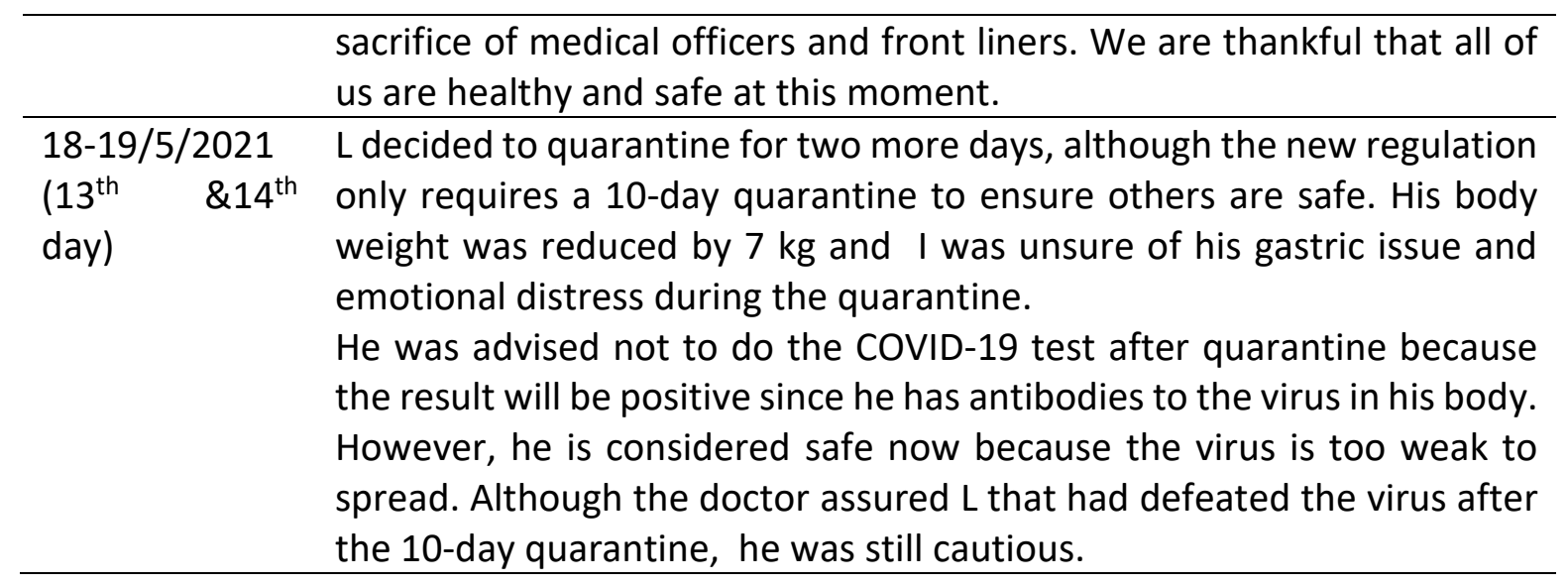

\section{Common Adverse Psychological Consequences of Quarantine}

During the pandemic, conflicting messages from authorities and public health departments are one of the main stressors contributing to extensive emotional distress and increased risk of adverse psychological consequences (Pfefferbaum \& North, 2020). The common stress responses have behavioral and psychological effects on infections patients such as depression, insomnia, fear, panic attacks, illness anxiety, boredom, or engaging in the use of substances (Banerjee, 2020; Pfefferbaum \& North, 2020). Ducker (2021) reported that a mild COVID-19 infection may cause irreversible physical and mental alterations even after recovering from the disease. Furthermore, a review elaborated on the psychological impact of stressors during and post-quarantine (Brooks et al., 2020). During quarantine, the short duration was associated with less pronounced psychological effects such as fear of infecting others, boredom, frustration, insufficient basic supplies, and lack of information from authorities. However, common stressors post-quarantine are mainly financial loss and stigma.

A research conducted among the Malaysian adult population found mental health issues became more severe as the COVID-19 pandemic is prolonged (Wong et al., 2021). The Malaysian public is increasingly exposed to depressive disorders while the pandemic continued. The Depression Anxiety Stress Scale (DASS-21) score shows that the prevalence of depression among the participants is close to $60 \%$. There is a need to carry out more epidemiological studies to determine the adverse psychological effects of the pandemic and how to support and reduce such effects on affected patients, caregivers, and the public. COVID-19 has a lasting and long-term impact on mental health, but to date, these adverse effects are still not determined (Gilbody et al., 2021).

Of note, the rate of suicide cases has increased in Malaysia during the COVID-19 pandemic (Kamel 2020; Wong et al., 2021) as well as in other Asian countries such as Bangladesh and India (Mamun \& Griffiths, 2020). Aside from Malaysians, the hopelessness feeling during the pandemic is experienced by foreign workers in the country. The main causes are attributed to loss of jobs, financial issues, debts, loss of loved ones, and uncertain future (Dermawan, 2020). Therefore, self-efficacy, self-acceptance, self-compassion, and selfcare should be explored to reduce the negative effects on the psychology of patients and caregivers.

\section{Self-Acceptance}

The stigma associated with infectious diseases might be experienced by individuals who recover from COVID-19, and it represents one of the common mental health challenges (Singh et al., 2020). This may happen to either the caregiver or family members of the patient. To 
face this issue, we need to accept the fact that L was a COVID-19 patient and he had recovered. He did his very best to avoid contracting the virus and should not be blamed for contracting it. We can just accept what had happened and play our role by not spreading the disease to others.

Brooks et al (2020) stated that stigma was one of the post-quarantine stressors and remarkably evident in the literature. The author reported that people who contracted the disease were treated with skepticism and unease, fewer social invitations, critical comments, and avoided by others. To reduce the effects of the stigma, social media plays an important role. Positive stories of people who have recovered from COVID-19 and caregivers' experiences of supporting a loved one through recovery should be magnified (Jiloha, 2020). Likewise, enhanced information to educate people that recovered patients are no longer capable of transmitting the virus to others may help to reduce the stigmatization. In the same vein, emotional support to the survivors of COVID-19 could also be encouraged.

\section{Self-Compassion}

At this difficult time, we can be more forgiving and compassionate to ourselves. We really have no idea or proof of where he contracted the virus, but we have to forgive the spreader. No one wants to get infected with COVID-19. The spreader might have contracted the virus from an asymptomatic patient and both may be unaware of their status. I reassured myself that I did my best to take care of $L$ and the children during the quarantine. At the same time, I am sure that my needs were also fulfilled.

Children are expected to do house chores with physical distancing. In the Asian culture, mothers always play a sacrificial role but I do not want to follow that trend. I have my stress and work commitment, and I need family members to share the burden. I admitted that I am not a perfect mother, wife and I prefer an equal right in the family. Acknowledging the fact that I am not strong and needed to be supported both physically and emotionally, I shared my shortcomings and feelings with my children during the quarantine. I find ways that helped me to manage my negative feelings by meditation, writing in a diary, sharing my thoughts with my children, and seek help if needed. Literature reviews indicated that reflective practices and small-group discussions are ways to develop self-awareness. In addition, two emotional health interventions such as mindfulness and stress management practices have been shown to stimulate resilience and reduce burnout (Heath et al., 2020).

\section{Self-Care}

Improve awareness of self-care promotes well-being and reduces anxiety and feelings of isolation (Kuhn \& Flanagan, 2017; Saltzman et al., 2020). The valuable concept of self-care is its emphasis on individuals taking a proactive role in maintaining their well-being (Martins et al., 2021). Although results from studies indicated that involvement in self-care activities may reduce stress, emotional intelligence remains the most significant factor (Martins et al., 2021). Moreover, there are many unpredictable incidents and unknown situations, especially during the pandemic. Uncertainty with the future is the main reason affecting mental health during lockdowns. Therefore, self-efficacy can be encouraged to prevent social isolation and helplessness. People need to be encouraged to practice self-care for themselves and their families (Banerjee, 2020), which is expected to improve physical and mental health during stay home orders (Martins et al., 2021). In this era of a pandemic, technology is much needed to raise awareness of self-care and promote well-being (Saltzman et al., 2020). Online-based 
mental health support is recommended (Mamun \& Griffiths, 2020), and 24 hours "Talian Kasih" hotline will help to deal with mental distress among Malaysians during FMCO.

We need to do what we can for ourselves, focus on what we can control, and accept what is beyond our control. Having regular meals, sleep, exercise, and rest are equally vital (Banerjee, 2020; Walton et al., 2020), focus on the positives, and appreciate the good things of life, including family and friends (Walton et al., 2020). In fact, a change in mindset is valuable. Relating this to my experience, I felt isolated during the quarantine. I had to change my perspective because of the privilege to have time for myself. Therefore, I treated the opportunity as "Me time" and reminded myself that such an opportunity is rare and should be appreciated. As the quarantine proceeded, I was more mindful of my thought, whether positive or negative, and I was more aware at every moment during the period. All this while, my life had always been to rush for work, classes, house chores, and research dateline. Now, I had to focus on one thing: Be myself.

Studies indicated that females were more likely to experience higher psychological symptoms during the pandemic compared to males. Evidence revealed that there are gender differences when coping with traumatic events. Females are generally more susceptible to stress and anxiety in response to disturbing conditions (McLean et al., 2011; Wong \& Alias, 2020; Wong et al., 2021). Therefore, intervention strategies and policies for public health emergencies involve a gender-based approach to address the issue and avoid health inequities (Jacques-Aviño et al., 2020).

Besides external supports, females can also improve their mental health internally by practicing mindfulness, keeping self-care journals, yoga, or any exercise that is beneficial to health. With the awareness of the present moment, maintaining mindfulness, and be open to the unavoidable stress and changes that are now considered part of our lives, especially at this critical time. Be self-compassionate, understand that we are not perfect, and finding ways to improve our condition according to our pace. Also, we need to be aware of our emotional changes and practice self-care support in small and doable ways, which will improve our mental well-being (Coyne et al., 2020).

\section{Conclusion}

Everyone is equal during this pandemic. However, our individual experiences are different, thus leading to diverse feelings and responses. As females, we play multiple roles in taking care of our family and work, and we are encouraged to be self-reliant during normal peaceful life and at difficult times. When a disaster strikes, females are expected to take more responsibilities than usual. People with high levels of self-efficacy are keener to practice selfcare in difficult times. Together, self-efficacy, self-acceptance, self-compassion, and self-care are vital ingredients to sustain the well-being of a female. These events contribute to female mental health and well-being during the pandemic and beyond the COVID-19 era.

\section{References}

Bandura, A. (1997). Self-efficacy: The exercise of control. W. H. Freeman and Company.

Banerjee, D. (2020). The COVID-19 outbreak: Crucial role the psychiatrists can play. Asian Journal of Psychiatry, 50, 102014.

Bernama (2021, May 18). Emergence of new Covid-19 variants worrying, says Health DG. The Edge Market. https://www.theedgemarkets.com/article/emergence-new-covid19variants-worrying-says-health-dg 
Brooks, S. K., Webster, R. K., Smith, L. E., Woodland, L., Wessely, S., Greenberg, N., \& Rubin, G. J. (2020). The psychological impact of quarantine and how to reduce it: Rapid review of evidence. The Lancet, 395, 10227.

Coyne, L. W., Gould, E. R., Grimaldi, M., Wilson, K. G., Baffuto, G., \& Biglan, A. (2020). First things first: Parent psychological flexibility and self-compassion during COVID19. Behavior Analysis in Practice, 1-7.

Del Nonno, F., Colombo, D., Nardacci, R., \& Falasca, L. (2021). Fatal pulmonary arterial thrombosis in a COVID-19 patient, with asymptomatic history, occurred after swab negativization. Thrombosis Journal, 19(1), 1-6.

Dermawan, A. (2020). CAP: Covid-19 pandemic is a psychological time-bomb. New Straits Times.https://www.nst.com.my/news/nation/2020/12/647524/cap-covid-19pandemic-psychological-time-bomb

Dhont, S., Derom, E., Van Braeckel, E., Depuydt, P., \& Lambrecht, B. N. (2020). The pathophysiology of 'happy'hypoxemia in COVID-19. Respiratory Research, 21(1), 1-9.

Ducker, J. (2021). Mental health effects common among mild and severe cases of COVID-19. News Medical Life Sciences. https://www.news-medical.net/news/20210604/Mentalhealth-effects-common-among-mild-and-severe-cases-of-COVID-19.aspx

Gilbody, S., Littlewood, E., Gascoyne, S., McMillan, D., Ekers, D., Chew-Graham, C. A., ... \& Wright, J. (2021). Mitigating the impacts of COVID-19: Where are the mental health trials?. The Lancet Psychiatry, 1-3.

Heath, C., Sommerfield, A., \& von Ungern-Sternberg, B. S. (2020). Resilience strategies to manage psychological distress among healthcare workers during the COVID-19 pandemic: A narrative review. Anaesthesia, 75(10), 1364-1371.

Hirschmann, R. (2021). COVID-19 confirmed cases Malaysia 2021, by state. Statista. https://www.statista.com/statistics/1107426/malaysia-covid-19-confirmed-cases-bystate/

Holder, J. (2021). Tracking Coronavirus vaccinations around the world. The New York Times. https://www.nytimes.com/interactive/2021/world/covid-vaccinations-tracker.html

Hong, J., Chang, R. \& Varley, K. (2021, May 25). The Covid resilience ranking: U.S., Europe rise in best places to be in Covid; Asia suffers. Bloomberg. https://www.bloomberg.com/graphics/covid-resilience-ranking/

Jacques-Aviñó, C., López-Jiménez, T., Medina-Perucha, L., De Bont, J., Gonçalves, A. Q., Duarte-Salles, T., \& Berenguera, A. (2020). Gender-based approach on the social impact and mental health in Spain during COVID-19 lockdown: A cross-sectional study. BMJ Open, 10(11), e044617.

Jiloha, R. C. (2020). COVID-19 and mental health. Epidemiology International, 5(1), 7-9.

Kamel, H. (2020). Suicide cases on the rise amid pandemic. The Malaysian Reserve. https://themalaysianreserve.com/2020/11/11/suicide-cases-on-the-rise-amidpandemic/

Kelland, K. (2021). UK COVID-19 variant has significantly higher death rate, study finds. Reuters. https://www.reuters.com/article/us-health-coronavirus-variant-britainidUSKBN2B213E

Kuhn, C. M., \& Flanagan, E. M. (2017). Self-care as a professional imperative: Physician burnout, depression, and suicide. Canadian Journal of Anesthesia/Journal canadien d'anesthésie, 64, 158-168.

Le Page, M., Wilson, C., Hamzelou, J., Wong, S., Lawton, G., Vaughan, A., Quilty-Harper, C., \& Liverpool, L. (2021). Covid-19 news: UK cases could hit 100,000 a day, says health 
minister. New Scientist. https://www.newscientist.com/article/2237475-covid-19news-delta-variant-now-causing-91-per-cent-of-uk-cases/\#ixzz6xT74kHiM

Mamun, M. A., \& Griffiths, M. D. (2020). First COVID-19 suicide case in Bangladesh due to fear of COVID-19 and xenophobia: Possible suicide prevention strategies. Asian Journal of Psychiatry, 51, 102073.

Martins, E. B, Luis, E. O., Fernández-Berrocal, P., Martínez, M., \& Sarrionandia, A. (2021). The role of emotional intelligence and self-care in the stress perception during COVID-19 outbreak: An intercultural moderated mediation analysis. Personality and Individual Differences, 177, 110679.

McLean, C. P., Asnaani, A., Litz, B. T., \& Hofmann, S. G. (2011). Gender differences in anxiety disorders: Prevalence, course of illness, comorbidity and burden of illness. Journal of Psychiatric Research, 45(8), 1027-1035.

Motlagh, A. E., Babazadeh, R., Akhlaghi, F., \& Esmaily. H. (2019). Effect of an educational intervention program based on Bandura's self-efficacy theory on self-care, self-efficacy, and blood sugar levels in mothers with pre-diabetes during pregnancy. Evidence Based Care, 9(2), 53-64.

Pfefferbaum, B., \& North, C. S. (2020). Mental health and the Covid-19 pandemic. New England Journal of Medicine, 383(6), 510-512.

Povera, A., \& Arumugam, T. (2021). Surge in daily Covid-19 cases due to Hari Raya. New Straits Times. https://www.nst.com.my/news/nation/2021/05/692223/surge-daily-covid-19cases-due-hari-raya

Povera, A., Arumugam, T., \& Teoh P. Y. (2021). Total lockdown much needed to bring down new Covid-19 cases. New Straits Times.

https://www.nst.com.my/news/nation/2021/05/694442/total-lockdown-muchneeded-bring-down-new-covid-19-cases

Salim, S. (2020). Forty-four Covid-19 cases died before reaching hospital in second, third pandemic waves - Health D-G. The Edge Markets. https://www.theedgemarkets.com/article/fortyfour-covid19-cases-died-reachinghospital-third-pandemic-wave-\%E2\%80\%94-health-dg

Saltzman, L. Y., Hansel, T. C., \& Bordnick, P. S. (2020). Loneliness, isolation, and social support factors in post-COVID-19 mental health. Psychological Trauma: Theory, Research, Practice, and Policy, 12(S1), 55-57.

Singh, S., Bhutani, S., \& Fatima, H. (2020). Surviving the stigma: Lessons learnt for the prevention of COVID-19 stigma and its mental health impact. Mental Health and Social Inclusion, 24(3), 145-149.

Walton, M., Murray, E., \& Christian, M. D. (2020). Mental health care for medical staff and affiliated healthcare workers during the COVID-19 pandemic. European Heart Journal: Acute Cardiovascular Care, 9(3), 241-247.

Wong, L. P., \& Alias, H. (2021). Temporal changes in psychobehavioural responses during the early phase of the COVID-19 pandemic in Malaysia. Journal of Behavioral Medicine, 44(1), 18-28.

Wong, L. P., Alias, H., Md Fuzi, A. A., Omar, I. S., Mohamad Nor, A., Tan, M. P., ... \& Chung, I. (2021). Escalating progression of mental health disorders during the COVID-19 pandemic: Evidence from a nationwide survey. PloS One, 16(3), e0248916. 